\title{
Biocontrol potential of entomopathogenic fungi, nematodes and bacteria against Rhynchophorus ferrugineus (Olivier)
}

\author{
Muhammad Yasin ${ }^{1,3^{*}}$, Waqas Wakil ${ }^{2,3}$, Mirza Abdul Qayyum4 ${ }^{4}$ Sajjad Ali , Asif Sajjad ${ }^{1}$, \\ Muhammad Anjum Aqueel ${ }^{1}$ and Muhammad Shakeel ${ }^{5}$
}

\begin{abstract}
Background: The red palm weevil (RPW), Rhynchophorus ferrugineus (Olivier) (Coleoptera: Curculionidae), is a serious threat to date palms across the globe, causing heavy yield losses. The pest inflicts damage to palms stem and destroys vascular system; resultantly lower the vigor and affect the growth and yield. For ecological farming system, biological control of the pest is gaining increased interest due to hosts' specificity, safety to human, animal and non-target organisms, and their compatibility to environment.
\end{abstract}

Results: In laboratory assay, Beauveria bassiana, Heterorhabditis bacteriophora and Bacillus thuringiensis var. kurstaki $(B t-k)$ alone and in combination against sixth instar larvae and adults of four distinct populations of RPW were applied. H. bacteriophora was more effective, followed by B. bassiana and Bt-k in alone treatments. While in combined treatments, the highest mortality was recorded for H. bacteriophora + B. bassiana combination (100\% for both stages), followed by H. bacteriophora + Bt-k, (larvae 100\%; adults 94.24\%) and B. bassiana + Bt-k treatments (larvae: 87.01\%; adults: 80.53\%). Maximum rate of mycosis (larvae 85.74\%; adults 69.07\%), sporulation (larvae 189.22 conidia $\mathrm{ml}^{-1}$; adults 164.56 conidia $\mathrm{ml}^{-1}$ ), cadavers affected by nematodes (larvae 92.4\%; adults $81.29 \%$ ) and nematode production (larvae $178.78 \mathrm{IJ} \mathrm{ml}^{-1}$; adults $153.44 \mathrm{IJs} \mathrm{ml}^{-1}$ ) was observed where B. bassiana or $\mathrm{H}$. bacteriophora was applied alone and the lowest (larvae $122.78 \mathrm{IJs} \mathrm{ml}^{-1}$; adults: $103.22 \mathrm{IJs} \mathrm{ml}^{-1}$ ) was recorded for $\mathrm{H}$. bacteriophora + B. bassiana combination.

Conclusions: Entomopathogens can be effectively used alone and/or in integration to control RPW populations. Natural capability of entomopathogens to infect and disseminate into other hosts makes them excellent biocontrol agents to be incorporated in the IPM plan of RPW and to make palm growers confident with the use of the most promising microbial control agents.

Keywords: Rhynchophorus ferrugineus, Red palm weevil, Beauveria bassiana, Heterorhabditis bacteriophora, Bacillus thuringiensis, Entomopathogens, Potential

\section{Background}

The red palm weevil (RPW), Rhynchophorus ferrugineus (Olivier) (Coleoptera: Curculionidae), is an invasive pest which has invaded and fully established in more than 60 countries of the world, infecting 40 palm

\footnotetext{
*Correspondence: yasin_1876@yahoo.com

1 Department of Entomology, The Islamia University of Bahawalpur,

Bahawalpur 63100, Pakistan

Full list of author information is available at the end of the article
}

species belonging to 23 different genera (Ashry et al. 2020). Heavy use of synthetic chemicals causes environmental damage, endangers biological diversity and exert negative impact on human and non-target organisms (Abdel-Raheem et al. 2020). Moreover, pesticides do not effectively manage the pest due to their cryptic nature and lead to the development of insecticide resistance against it. Considering these concerns, there is a growing demand to adopt alternate control measures which are 
safer to human and non-target, and compatible to environment (Mendesil et al. 2016).

Microbial entomopathogens including entomopathogenic fungi (EPFs), entomopathogenic nematodes (EPNs) and entomopathogenic bacteria (EPBs) are widely used as potential alternatives to these chemicals. EPFs are commonly found in the nature and cause epizootics in insect populations, thus play significant role in regulating insect population. EPFs from various strains of Beauveria bassiana (Bals.-Criv.) Vuill. and Metarhizium anisopliae (Metchnikoff) (Ascomycota: Hypocreales) have been found associated with RPW and among the most relevant biological agents (Faleiro 2006). Bacillus thuringiensis (Berliner) is another important microbial control agent which holds a prominent position among commercial chemical compounds important for agricultural insect pests. Various researchers have evaluated the pathogenic potential of $B$. thuringiensis against RPW and revealed its successful control (Manachini et al. 2009). $B$. thuringiensis causes feeding inhibition due to midgut damage in the treated larvae. EPNs have been declared an efficient entomopathogens against a variety of insects in integrated pest management program (IPM) including RPW (Manzoor et al. 2020). They are obligate parasites belonging to the families Steinernematidae and Heterorhabditidae which kill their host with the aid of mutualistic bacterium present in their intestine (Poinar 1990).

The intervention of more than one biocontrol agent can enhance the efficacy of the other partners; many studies have been conducted in this regard. The combined effect of B. bassiana and B. thuringiensis working synergistically delivered more harm to insect pests (Wraight and Ramos 2005). Similarly, the combined applications of EPNs and EPFs have been evaluated against different insect pests including RPW (Manzoor et al. 2020). Hence, integrated practices can be a hint for those, who are willing to manage RPW.

Therefore, the present study was designed to investigate the pathogenicity of $H$. bacteriophora, B. bassiana and $B$. thuringiensis var. kurstaki (Bt-k) against larvae and adult of RPW populations under laboratory conditions.

\section{Methods}

\section{RPW collection and rearing}

Four different populations of RPW were collected from Layyah, Dera Ismail Khan (D.I. Khan), Muzaffargarh and Rahim Yar Khan (R.Y. Khan), Punjab, Pakistan. Larvae, pupae and adults were collected from infested and fallen trees. Samples were collected and kept in separate plastic boxes assigned for a specific stage and brought to the laboratory until enough collection was done. Further multiplication for one generation was carried out in Microbial Control Laboratory, Department of
Entomology, University of Agriculture, Faisalabad, Pakistan. Larvae were offered by pieces of sugarcane (Saccharum officinarum L.; Poales: Poaceae) stem for feeding and pupation, while shredded sugarcane pieces were offered to the adults for feeding and as a substrate for oviposition. After pupation, pupal cocoons were kept in separate plastic jars for adult emergence in an incubator. Upon emergence, weevils were shifted to the adult's jar for feeding, mating and oviposition. Colony was developed in plastic boxes $(30 \times 60 \times 60 \mathrm{~cm})$ having a lid, covered with mesh wire gauze (60 mesh size) in the middle (10 cm diameter) for aeration. Adult's diet was changed every three days and replaced sugarcane pieces were kept in separate jars for egg hatching. After egg hatching, neonates were allowed to feed for 3 days in the same set and then shifted to the sugarcane sets for feeding and pupation. Larvae were shifted to the new sugarcane sets every week until pupation. The rearing conditions were maintained at $25 \pm 2{ }^{\circ} \mathrm{C}, 65 \pm 5 \% \mathrm{RH}$ and a 12: 12 (D: L) hrs. photoperiod (Wakil et al. 2017).

Preparation of Bacillus thuringiensis spore-crystal mixtures Commercial formulation of $B$. thuringiensis var. kurstaki $(B t-k)\left(\right.$ Dipel $\left.^{\circledR}\right)$ was obtained from National Center for Genetic Engineering and Biotechnology (BIOTEC), Thailand. This strain was, then, subjected to sporulation by culturing in $50 \mathrm{ml}$ nutrient broth media. Harvesting of culture was carried out by centrifugation at $6000 \mathrm{rpm}$ for 15 min (Hernández et al. 2005). The pellets formed resultantly were washed twice in cold $1 \mathrm{M} \mathrm{NaCl}$ and thrice in sterile distilled water (SDW), re-suspended in distilled water $(5 \mathrm{ml})$. From the suspension formed, $1 \mathrm{ml}$ was centrifuged for $5 \mathrm{~min}$ at 10,000 rpm, dried for $4 \mathrm{~h}$. at $37^{\circ} \mathrm{C}$ and weighed (Wakil et al. 2017).

\section{Nematode culture}

The IJs of $H$. bacteriophora were obtained from the culture collection of Microbial Control Laboratory. $H$. bacteriophora was maintained in third instar Galleria mellonella (L.) (Lepidoptera: Pyralidae) larvae, following the procedure of Kaya and Stock (1997).

\section{Fungal spores}

The fungal isolate of $B$. bassiana (WG-43), used in the study, was taken from the culture collection of Microbial Control Laboratory, originally isolated from dead cadaver of RPW. Fungi were sub-cultured on Sabouraud Dextrose Agar (BD, Becton, Dickisonand Company sparks, MD 21152 USA). Conidial suspension was prepared with 0.01\% Tween-80 (Merck, KGaA, Darmstadt, Germany) in sterile distilled water and conidial concentration 
of $1 \times 10^{7}$ conidia $\mathrm{ml}^{-1}$ determined using a Neubauer hemocytometer.

\section{Treatment with Beauveria bassiana}

Sixth instar RPW larvae and adults of uniform age from each population were directly immersed into the conidial suspensions for 60 and $90 \mathrm{~s}$, respectively, and control was treated with aqueous solution containing $0.01 \%$ Tween80. The treated and control insects were individually shifted to $150 \mathrm{ml}$ cylindrical plastic cups (10 cups per replication), each measuring $6 \mathrm{~cm}$ in height with $6 \mathrm{~cm}$ diameter. The tops of cups were covered with fine mesh in order to avoid the insects to escape. A piece of $2 \times 2$ $\mathrm{cm}^{2}$ artificial diet (Agar, brewer's yeast, wheat germ, corn flour, ascorbic acid, benzoic acid, amino acid-vitamin mix, chloramphenicol and nipagin) (Martín and Cabello 2006) was kept in the center of the cups for larvae, and a shredded sugarcane piece was offered to the adults. The causal agent of dead larvae or adults was confirmed by shifting the cadavers into a Petri dish lined with wet filter paper and incubating them at $25 \pm 2{ }^{\circ} \mathrm{C}$ and $70 \pm 5 \% \mathrm{RH}$ for up to 15 days.

\section{Treatment with Bacillus thuringiensis var. kurstaki (Bt-k)}

Sixth instar RPW larvae, from each population, were individually offered with artificial diets (Martín and Cabello 2006) and mixed with the diluted spore-crystal $\left(70 \mu \mathrm{g} \mathrm{g}^{-1}\right)$. To each larva, Bt-k treated diet piece of $\left(2 \times 2 \mathrm{~cm}^{2}\right)$ was provided to feed in plastic cups, and for adults, shredded sugarcane pieces were dipped in known $\left(70 \mu \mathrm{g} \mathrm{g}^{-1}\right)$ concentration of $B t-k$ for $90 \mathrm{~s}$ and offered to respective population.

\section{Treatment with Heterorhabditis bacteriophora}

$H$. bacteriophora suspension was prepared at a concentration of $300 \mathrm{IJs} \mathrm{ml}^{-1}$ in glass jars, and $1 \mathrm{ml}$ of suspension was poured into the $150 \mathrm{ml}$ cylindrical plastic cups $(6 \times 6 \mathrm{~cm})$ lined with damp Whatman filter paper. The cups were covered with a fine mesh in order to avoid the insect escape. After pouring nematodes, $30 \mathrm{~min}$ time was given for their even distribution on filter paper (Atwa and Hegazi 2014). A small piece of artificial diet $2 \times 2 \mathrm{~cm}^{2}$ was placed in middle of the cups as a food source for larvae and provided with new food every day. In each cup, one sixth instar larva from each population was placed on top of the filter paper. Same procedure was repeated for adult population and shredded sugarcane pieces were offered as food source, while control treatment received $1 \mathrm{ml}$ of distilled water. Dead individuals were transferred to the modified White traps (White 1927) and left for 10 days for IJs emergence. The insects exhibiting typical odor and color (signs for nematode infestation) were considered to be killed by nematodes (Woodring and Kaya 1988).

\section{Treatment with Beauveria bassiana, Heterorhabditis} bacteriophora and Bt-k

For integrated application of $B$. bassiana $+B t-k$, sixth instar larvae and adults from each population were directly immersed into the conidial suspensions for 60 and $90 \mathrm{~s}$, respectively, and shifted the larvae to Bt-k treated diet and adults to $B t-k$ dipped shredded sugarcane pieces. For B. bassiana and H. bacteriophora combination, larvae and adults were immersed in fungal spores and released on nematode treated filter paper. While, in case of $H$. bacteriophora and Bt-k combination, larvae and adults were fed by $B t-k$ treated diet and $B t-k$ dipped sugarcane pieces respectively, and placed in plastic cups with nematode treated filter papers, individually. Mortality data were recorded after 7,14 and 21 days of the treatments, each treatment was replicated 3 times with 10 individuals and whole bioassay was repeated thrice to avoid the pseudo-replication phenomenon. All the treatments were incubated at $25 \pm 2{ }^{\circ} \mathrm{C}, 70 \pm 5 \% \mathrm{RH}$ and a 12 : 12 (D: L) hrs. photoperiod.

\section{Sporulation and nematode production}

Mycosed larvae, after 14 days of incubation, were vortexed for $30 \mathrm{~min}$ in distilled water containing $0.01 \%$ Tween-80, and number of spores was estimated in $1 \mathrm{ml}$ from the suspension using a hemocytometer. Concentration of IJs was measured in $1 \mathrm{ml}$ sample from the final solution by counting the IJs with the help of a Peters' slide and microscope.

\section{Statistical analysis}

The mortality in control treatments was $<5 \%$. It was not included in the analysis and adjusted with Abbott's formula [Corrected mortality $(\%)=(1-$ insect population in treated unit after treatment/insect population in control unit after treatment) $\times 100$ ] (Abbott 1925). The data regarding mortality, mycosis, sporulation and percentage of larvae and adults affected and nematode production were subjected to factorial analysis of variance (ANOVA) in Minitab (Minitab 2003). Means were separated using Tukey's Kramer test (HSD) (Sokal and Rohlf 1995) at 5\% significance level to evaluate the impact of treatments on mortality and studied parameters.

\section{Results}

\section{Mortality of larvae and adult}

The results of present study revealed that the larval and adult mortality was significantly affected by the main effects and their associated interactions, except Treatment $\times$ Population, Exposure interval $\times$ Population and Treatment $\times$ Exposure interval $\times$ Population (Table 1 ). There was non-significant difference in mortalities of 
Table 1 ANOVA parameters for the main effects and associated interactions for mortality rates of Rhynchophorus ferrugineus larvae and adults

\begin{tabular}{|c|c|c|c|c|c|}
\hline \multirow[t]{2}{*}{ S.O.V } & \multirow[b]{2}{*}{$d f$} & \multicolumn{2}{|l|}{ Larvae } & \multicolumn{2}{|l|}{ Adult } \\
\hline & & $F$ & $P$ & $F$ & $P$ \\
\hline Treatment & 5 & 454.81 & $\leq 0.05$ & 437.56 & $\leq 0.05$ \\
\hline Exposure interval & 2 & 1546.71 & $\leq 0.05$ & 1099.79 & $\leq 0.05$ \\
\hline Population & 4 & 25.54 & $\leq 0.05$ & 17.88 & $\leq 0.05$ \\
\hline Treatment $\times$ Exposure interval & 10 & 19.98 & $\leq 0.05$ & 26.11 & $\leq 0.05$ \\
\hline Treatment $\times$ Population & 20 & 0.58 & 0.92 & 0.64 & 0.88 \\
\hline Exposure interval $\times$ Population & 8 & 0.93 & 0.49 & 1.24 & 0.27 \\
\hline Treatment $\times$ Exposure interval $\times$ Population & 40 & 0.73 & 0.89 & 0.41 & 0.99 \\
\hline Error & 550 & - & - & - & - \\
\hline Total & 647 & - & - & - & - \\
\hline
\end{tabular}

larvae and adults $(P \leq 0.05)$ among the tested populations after 7 days of exposure, except $B t-k+H$. bacteriophora for larvae (Table 2). Similarly, non-significant difference in mortalities $(P \leq 0.05)$ was observed at 14 days post exposure, except $B t-k+B$. bassiana, $B t-k+H$. bacteriophora, and B. bassiana $+H$. bacteriophora for larvae, and B. bassiana $+H$. bacteriophora for adults (Table 3). Likewise, significant difference was also observed in mortalities for B. bassiana and $\mathrm{H}$. bacteriophora in sole application for larvae, and $B t-k+B$. bassiana and Bt-k+H. bacteriophora for adults in all populations after 21 days of application (Table 4).

Significant difference was observed among all the treatments for tested RPW populations after 7 days of exposure. The highest larval and adult mortality was recorded in combined treatments of $B$. bassiana $+H$. bacteriophora for all populations (Larvae: Layyah $51.68 \%$, R.Y. Khan 46.82\%, D.G. Khan 42.19\%, Muzaffargarh 39.40\%; Adults: Layyah 39.73\%, R.Y. Khan $36.08 \%$, D.G. Khan 32.37\%, Muzaffargarh 30.89\%), followed by $B t-k+H$. bacteriophora, Bt-k+B. bassiana, and sole application

Table 2 Mortality percentage of Rhynchophorus ferrugineus populations treated with Bt- $k\left(70 \mu \mathrm{g} \mathrm{g}^{-1}\right)$, Beauveria bassiana $\left(1 \times 10^{7}\right.$ conidia $\mathrm{ml}^{-1}$ ) and Heterorhabditis bacteriophora (300 $\mathrm{Js} \mathrm{ml}^{-1}$ ) applied alone or in combination after 7 days of exposure

\begin{tabular}{|c|c|c|c|c|c|c|c|}
\hline \multirow[t]{2}{*}{ Stage } & \multirow[t]{2}{*}{ Treatments } & \multicolumn{6}{|l|}{ Motility\% } \\
\hline & & Layyah & D.G. Khan & Muzaffargarh & R.Y. Khan & $F$ & $P$ \\
\hline \multirow[t]{8}{*}{ Larvae } & $B t-k$ & $9.47 \pm 0.78 \mathrm{e}$ & $6.47 \pm 0.55 d$ & $6.08 \pm 0.78 d$ & $7.93 \pm 0.71 \mathrm{e}$ & 0.38 & 0.77 \\
\hline & $\mathrm{Bb}$ & $13.48 \pm 1.18 \mathrm{de}$ & $10.47 \pm 1.12 \mathrm{~cd}$ & $8.39 \pm 1.01 \mathrm{~cd}$ & $11.68 \pm 1.16 \mathrm{de}$ & 0.30 & 0.82 \\
\hline & EPN & $25.57 \pm 1.39 \mathrm{~cd}$ & $21.57 \pm 1.38 b c$ & $19.58 \pm 1.17 \mathrm{bc}$ & $23.45 \pm 1.13 \mathrm{~cd}$ & 0.62 & 0.60 \\
\hline & $B t-k+B b$ & $32.28 \pm 1.61 b c$ & $28.36 \pm 1.46 a b$ & $25.06 \pm 1.30 b$ & $30.17 \pm 1.65 b c$ & 1.28 & 0.29 \\
\hline & $B t-k+E P N$ & $45.37 \pm 2.15 a b$ & $33.73 \pm 1.50 \mathrm{ab}$ & $28.08 \pm 1.57 \mathrm{ab}$ & $42.11 \pm 2.36 a b$ & 6.46 & $\leq 0.05$ \\
\hline & $\mathrm{Bb}+\mathrm{EPN}$ & $51.68 \pm 2.34 a$ & $42.19 \pm 2.51 a$ & $39.40 \pm 2.14 a$ & $46.82 \pm 2.54 a$ & 2.05 & 0.12 \\
\hline & $F$ & 24.8 & 30.5 & 18.8 & 14.4 & - & - \\
\hline & $P$ & $\leq 0.05$ & $\leq 0.05$ & $\leq 0.05$ & $\leq 0.05$ & - & - \\
\hline \multirow[t]{8}{*}{ Adults } & $B t-k$ & $6.54 \pm 0.70 d$ & $4.69 \pm 0.49 d$ & $4.02 \pm 0.53 c$ & $5.46 \pm 0.74 d$ & 0.24 & 0.87 \\
\hline & $\mathrm{Bb}$ & $10.46 \pm 1.12 d$ & $8.41 \pm 0.87 \mathrm{~cd}$ & $7.56 \pm 1.04 \mathrm{bc}$ & $9.29 \pm 1.09 \mathrm{~cd}$ & 0.16 & 0.92 \\
\hline & EPN & $19.18 \pm 1.24 \mathrm{~cd}$ & $14.90 \pm 1.01 \mathrm{bcd}$ & $13.22 \pm 1.35 b c$ & $16.51 \pm 1.21 \mathrm{~cd}$ & 0.72 & 0.54 \\
\hline & $B t-k+B b$ & $24.70 \pm 1.65 b c$ & $21.24 \pm 1.96 \mathrm{abc}$ & $19.69 \pm 1.56 a b$ & $22.06 \pm 1.56 b c$ & 0.31 & 0.81 \\
\hline & $B t-k+E P N$ & $35.41 \pm 2.35 a b$ & $28.84 \pm 2.11 a b$ & $27.09 \pm 1.75 b$ & $31.52 \pm 2.13 a b$ & 0.90 & 0.45 \\
\hline & $\mathrm{Bb}+\mathrm{EPN}$ & $39.73 \pm 2.09 a$ & $32.37 \pm 2.03 a$ & $30.89 \pm 2.05 a$ & $36.08 \pm 2.45 a$ & 1.38 & 0.26 \\
\hline & $F$ & 19.2 & 8.90 & 12.4 & 14.4 & - & - \\
\hline & $P$ & $\leq 0.05$ & $\leq 0.05$ & $\leq 0.05$ & $\leq 0.05$ & - & - \\
\hline
\end{tabular}




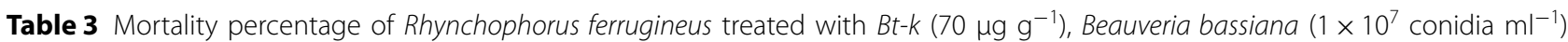
and Heterorhabditis bacteriophora $\left(300 \mathrm{IJ} \mathrm{ml}^{-1}\right.$ ) applied alone or in combination after 14 days of exposure

\begin{tabular}{|c|c|c|c|c|c|c|c|}
\hline \multirow[t]{2}{*}{ Stage } & \multirow[t]{2}{*}{ Treatments } & \multicolumn{6}{|c|}{ Insect populations } \\
\hline & & Layyah & D.G. Khan & Muzaffargarh & R.Y. Khan & $F$ & $P$ \\
\hline \multirow[t]{8}{*}{ Larvae } & $B t-k$ & $22.50 \pm 1.58 c$ & $20.67 \pm 1.39 c$ & $17.70 \pm 1.08 \mathrm{c}$ & $19.50 \pm 1.23 c$ & 0.43 & 0.73 \\
\hline & $\mathrm{Bb}$ & $31.02 \pm 1.81 \mathrm{c}$ & $27.76 \pm 1.85 c$ & $23.39 \pm 1.92 c$ & $25.64 \pm 1.08 c$ & 0.59 & 0.62 \\
\hline & EPN & $60.38 \pm 2.71 b$ & $55.66 \pm 2.44 b$ & $49.22 \pm 2.65 b$ & $51.57 \pm 2.18 b$ & 1.38 & 0.26 \\
\hline & $B t-k+B b$ & $65.24 \pm 3.10 \mathrm{~b}$ & $59.10 \pm 2.18 b$ & $52.55 \pm 2.77 b$ & $55.09 \pm 3.07 b$ & 3.39 & $\leq 0.05$ \\
\hline & $B t-k+E P N$ & $89.66 \pm 3.26 a$ & $83.10 \pm 3.72 \mathrm{a}$ & $74.57 \pm 3.14 a$ & $78.42 \pm 3.87 a$ & 4.07 & $\leq 0.05$ \\
\hline & $\mathrm{Bb}+\mathrm{EPN}$ & $97.37 \pm 2.73 a$ & $91.55 \pm 3.27 a$ & $82.68 \pm 3.86 a$ & $86.17 \pm 3.03 a$ & 3.67 & $\leq 0.05$ \\
\hline & F & 86.2 & 73.1 & 46.3 & 60.3 & - & - \\
\hline & P & $\leq 0.05$ & $\leq 0.05$ & $\leq 0.05$ & $\leq 0.05$ & - & - \\
\hline \multirow[t]{8}{*}{ Adults } & $B t-k$ & $17.40 \pm 1.46 c$ & $15.78 \pm 1.04 \mathrm{c}$ & $12.01 \pm 0.88 \mathrm{c}$ & $13.76 \pm 1.07 \mathrm{c}$ & 0.73 & 0.54 \\
\hline & $\mathrm{Bb}$ & $24.07 \pm 1.50 c$ & $21.85 \pm 1.28 \mathrm{c}$ & $17.85 \pm 1.33 \mathrm{~cd}$ & $20.52 \pm 1.32 c$ & 0.37 & 0.77 \\
\hline & EPN & $45.06 \pm 2.48 b$ & $40.40 \pm 1.65 b$ & $34.54 \pm 2.03 b c$ & $37.62 \pm 1.99 \mathrm{~b}$ & 0.93 & 0.43 \\
\hline & $B t-k+B b$ & $52.54 \pm 2.49 b$ & $48.01 \pm 2.14 b$ & $39.98 \pm 2.19 b$ & $43.27 \pm 2.75 b$ & 2.56 & 0.07 \\
\hline & $B t-k+E P N$ & $72.37 \pm 3.21 a$ & $67.77 \pm 3.10 \mathrm{a}$ & $61.64 \pm 2.93 a$ & $65.80 \pm 2.57 a$ & 1.48 & 0.23 \\
\hline & $\mathrm{Bb}+\mathrm{EPN}$ & $81.29 \pm 3.37 a$ & $75.74 \pm 3.34 a$ & $64.43 \pm 3.06 a$ & $70.18 \pm 2.28 a$ & 3.87 & $\leq 0.05$ \\
\hline & $F$ & 50.5 & 42.1 & 27.9 & 41.8 & - & - \\
\hline & $P$ & $\leq 0.05$ & $\leq 0.05$ & $\leq 0.05$ & $\leq 0.05$ & - & - \\
\hline
\end{tabular}

Mortality\% followed by the same letter within each treatment and insect populations are not significantly different; HSD test $P \leq 0.05$ (Bt-k: Bacillus thuringiensis var. kurstaki, Bb: Beauveria bassiana, EPN: Heterorhabditis bacteriophora)

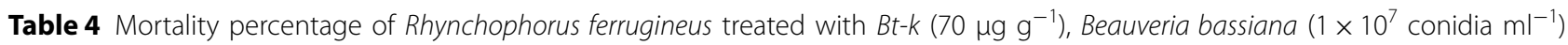
and Heterorhabditis bacteriophora $\left(300 \mathrm{Is} \mathrm{m}^{-1}\right.$ ) applied alone or in combination after 21 days of exposure

\begin{tabular}{|c|c|c|c|c|c|c|c|}
\hline \multirow[t]{2}{*}{ Stage } & \multirow[t]{2}{*}{ Treatments } & \multicolumn{6}{|c|}{ Insect populations } \\
\hline & & Layyah & R.Y. Khan & Muzaffargarh & D.G. Khan & $F$ & $P$ \\
\hline \multirow[t]{8}{*}{ Larvae } & $B t-k$ & $58.36 \pm 4.55 d$ & $54.66 \pm 4.46 c$ & $46.86 \pm 4.53 d$ & $49.78 \pm 2.45 c$ & 1.55 & 0.22 \\
\hline & $\mathrm{Bb}$ & $72.63 \pm 3.88 c$ & $66.79 \pm 3.45 c$ & $57.27 \pm 2.75 \mathrm{~cd}$ & $55.55 \pm 2.92 c$ & 6.04 & $\leq 0.05$ \\
\hline & EPN & $84.54 \pm 2.71 b c$ & $81.06 \pm 3.14 b$ & $70.45 \pm 3.19 b c$ & $73.92 \pm 2.74 b$ & 4.75 & $\leq 0.05$ \\
\hline & $B t-k+B b$ & $87.01 \pm 3.04 b$ & $82.17 \pm 2.90 b$ & $75.77 \pm 4.75 b$ & $78.24 \pm 2.39 b$ & 2.09 & 0.12 \\
\hline & $B t-k+E P N$ & $100.00 \pm 0.00 a$ & $98.41 \pm 1.58 a$ & $93.35 \pm 3.06 a$ & $95.57 \pm 2.85 \mathrm{a}$ & 1.75 & 0.17 \\
\hline & $\mathrm{Bb}+\mathrm{EPN}$ & $100.0 \pm 0.00 \mathrm{a}$ & $100.0 \pm 0.00 a$ & $100.0 \pm 0.00 a$ & $100.0 \pm 0.00 a$ & - & - \\
\hline & $F$ & 29.8 & 34.9 & 35.5 & 69.0 & - & - \\
\hline & $P$ & $\leq 0.05$ & $\leq 0.05$ & $\leq 0.05$ & $\leq 0.05$ & - & - \\
\hline \multirow[t]{8}{*}{ Adults } & $B t-k$ & $39.04 \pm 2.41 d$ & $32.56 \pm 3.80 d$ & $26.79 \pm 3.68 f$ & $30.74 \pm 2.96 f$ & 2.45 & 0.08 \\
\hline & $\mathrm{Bb}$ & $47.55 \pm 2.60 d$ & $43.07 \pm 4.15 d$ & $38.13 \pm 4.09 \mathrm{e}$ & $36.12 \pm 3.31 \mathrm{e}$ & 2.03 & 0.12 \\
\hline & EPN & $61.13 \pm 3.81 c$ & $58.15 \pm 3.25 c$ & $52.37 \pm 2.20 d$ & $54.35 \pm 1.82 \mathrm{~d}$ & 1.83 & 0.16 \\
\hline & $B t-k+B b$ & $80.53 \pm 2.66 b$ & $76.69 \pm 3.11 \mathrm{~b}$ & $67.96 \pm 3.92 \mathrm{c}$ & $71.04 \pm 3.18 c$ & 2.99 & $\leq 0.05$ \\
\hline & $B t-k+E P N$ & $94.24 \pm 2.28 \mathrm{a}$ & $90.03 \pm 2.82 a$ & $81.27 \pm 2.28 b$ & $86.48 \pm 1.46 b$ & 5.88 & $\leq 0.05$ \\
\hline & $\mathrm{Bb}+\mathrm{EPN}$ & $100.0 \pm 0.00 \mathrm{a}$ & $100.0 \pm 0.00 a$ & $100.0 \pm 0.00 a$ & $100.0 \pm 0.00 a$ & - & - \\
\hline & $F$ & 95.3 & 70.9 & 80.5 & 130 & - & - \\
\hline & $P$ & $\leq 0.05$ & $\leq 0.05$ & $\leq 0.05$ & $\leq 0.05$ & - & - \\
\hline
\end{tabular}

Mortality\% followed by the same letter within each treatment and insect populations are not significantly different; HSD test $P \leq 0.05$ (Bt-k: Bacillus thuringiensis var. kurstaki, Bb: Beauveria bassiana, EPN: Heterorhabditis bacteriophora)

of $H$. bacteriophora, B. bassiana and Bt-k (Table 2). The laboratory population was more susceptible, followed by D.G. Khan, R.Y. Khan and Muzaffargarh population at all exposure intervals. Likewise, after 14 and 21 days postexposure, combined treatment of B. bassiana $+H$. bacteriophora exhibited the highest larval and adult mortality 
rates, while the lowest one was recorded at $B t-k$ in individual applications for all RPW populations (Tables 3, 4). After last count, B. bassiana $+H$. bacteriophora treatment exhibited 100\% larval and adult mortality for all the populations, while $B t-k+H$. bacteriophora exhibited $100 \%$ larval mortality in laboratory population.

\section{Mycosis and sporulation}

Significant difference in the mycosis was observed for all RPW populations for both larvae (D.G. Khan: $F_{2}$, ${ }_{26}=11.2, P<0.01$; Layyah: $F_{2},{ }_{26}=21.6, P<0.01$; Muzaffargarh: $F_{2},{ }_{26}=30.8, P<0.01$; R.Y. Khan: $F_{2},{ }_{26}=13.2$, $P<0.01$ ) and adults (D.G. Khan: $F_{2},{ }_{26}=25.8, P<0.01$; Layyah: $F_{2}$, ${ }_{26}=7.20, P<0.01$; Muzaffargarh: $F_{2},{ }_{26}=30.8$, $P<0.01$; R.Y. Khan: $\left.F_{2},{ }_{26}=13.6, P<0.01\right)$. Maximum mycosed larvae (85.74\%) and adults (69.07\%) were observed in treatments, where B. bassiana was applied alone against larvae and adults, respectively, in laboratory population (Fig. 1a, b) however, low rate of mycosis was observed in the treatments where H. bacteriophora and B. bassiana were applied in combined manners. Similarly, significant difference in the sporulation was observed for all RPW populations for both larvae (D.G. Khan: $F_{2}$, ${ }_{26}=62.7, P<0.01$; Layyah: $F_{2},{ }_{26}=259, P<0.01$; Muzaffargarh: $F_{2},{ }_{26}=140, P<0.01$; R.Y. Khan: $F_{2},{ }_{26}=132, P<0.01$ ) and adults (D.G. Khan: $F_{2},{ }_{26}=163, P<0.01$; Layyah: $F_{2}$, ${ }_{26}=197, P<0.01$; Muzaffargarh: $F_{2},{ }_{26}=155, P<0.01$; R.Y. Khan: $\left.F_{2},{ }_{26}=138, P<0.01\right)$. Maximum sporulating larvae and (189.22 conidia $\left.\mathrm{ml}^{-1}\right)$ adults $(164.56$ conidia $\mathrm{ml}^{-1}$ ) were observed in treatments, where $B$. bassiana
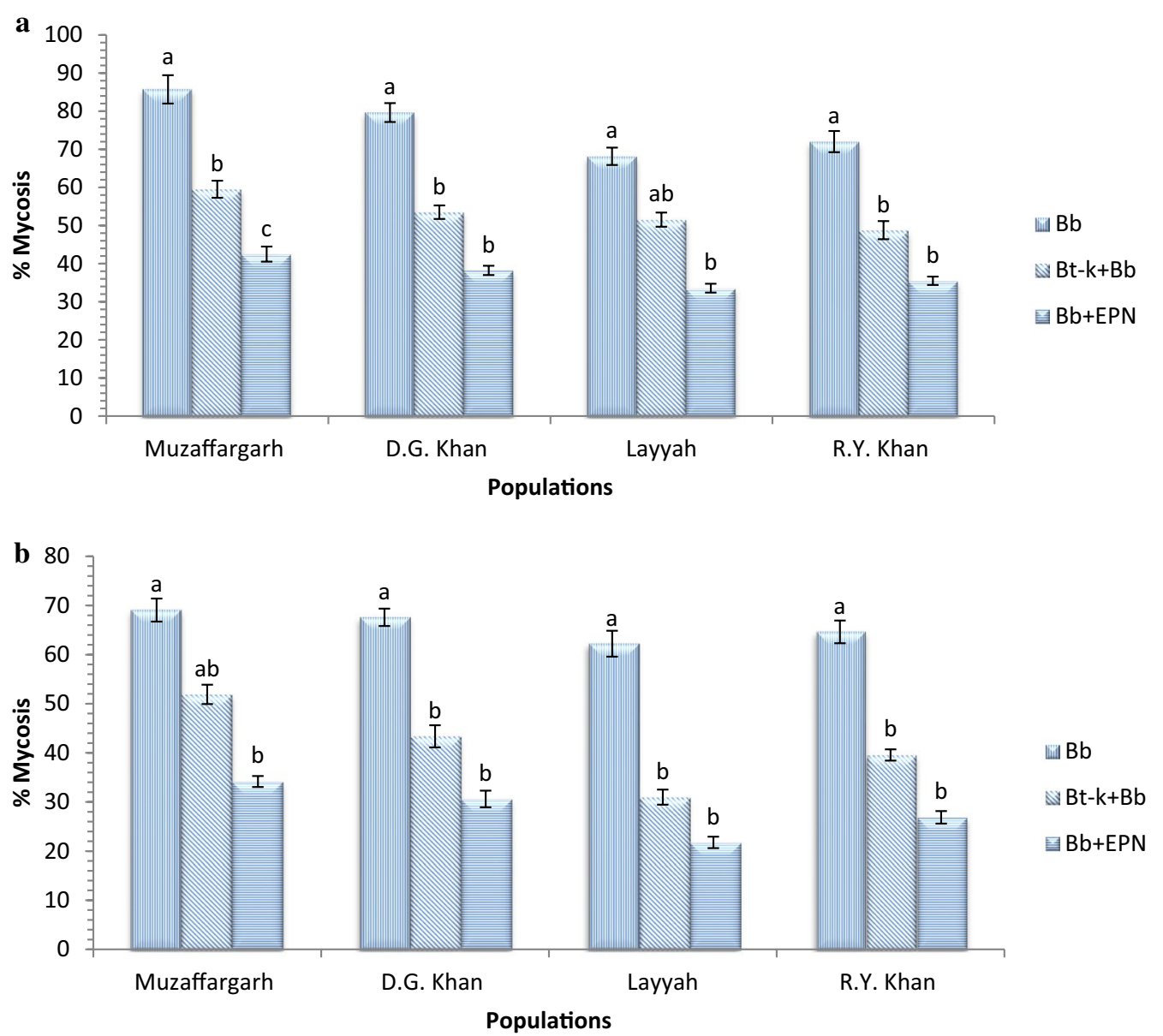

Fig. 1 a Mycosis percentage in Rhynchophorus ferrugineus larvae treated with Bt-k $\left(70 \mathrm{\mu g} \mathrm{g}^{-1}\right)$, Beauveria bassiana $\left(1 \times 10^{7} \mathrm{conidia} \mathrm{ml}^{-1}\right)$ and Heterorhabditis bacteriophora $\left(300 \mathrm{IJs} \mathrm{ml}^{-1}\right.$ ) applied alone or in combination. Percentage mycosis followed by the same letter within each treatment are not significantly different; HSD test $P \leq 0.05$ ((Bt-k: Bacillus thuringiensis var. kurstaki, Bb: Beauveria bassiana, EPN: Heterorhabditis bacteriophora). b Mycosis percentage in Rhynchophorus ferrugineus adults treated with Bt-k $\left(70 \mathrm{\mu g} \mathrm{g}^{-1}\right)$, Beauveria bassiana $\left(1 \times 10^{7}\right.$ conidia ml $\left.{ }^{-1}\right)$ and Heterorhabditis bacteriophora $\left(300 \mathrm{IJ} \mathrm{ml}^{-1}\right)$ applied alone or in combination. Percentage mycosis followed by the same letter within each treatment are not significantly different; HSD test $P \leq 0.05$ (Bt-k: Bacillus thuringiensis var. kurstaki, Bb: Beauveria bassiana, EPN: Heterorhabditis bacteriophora) 

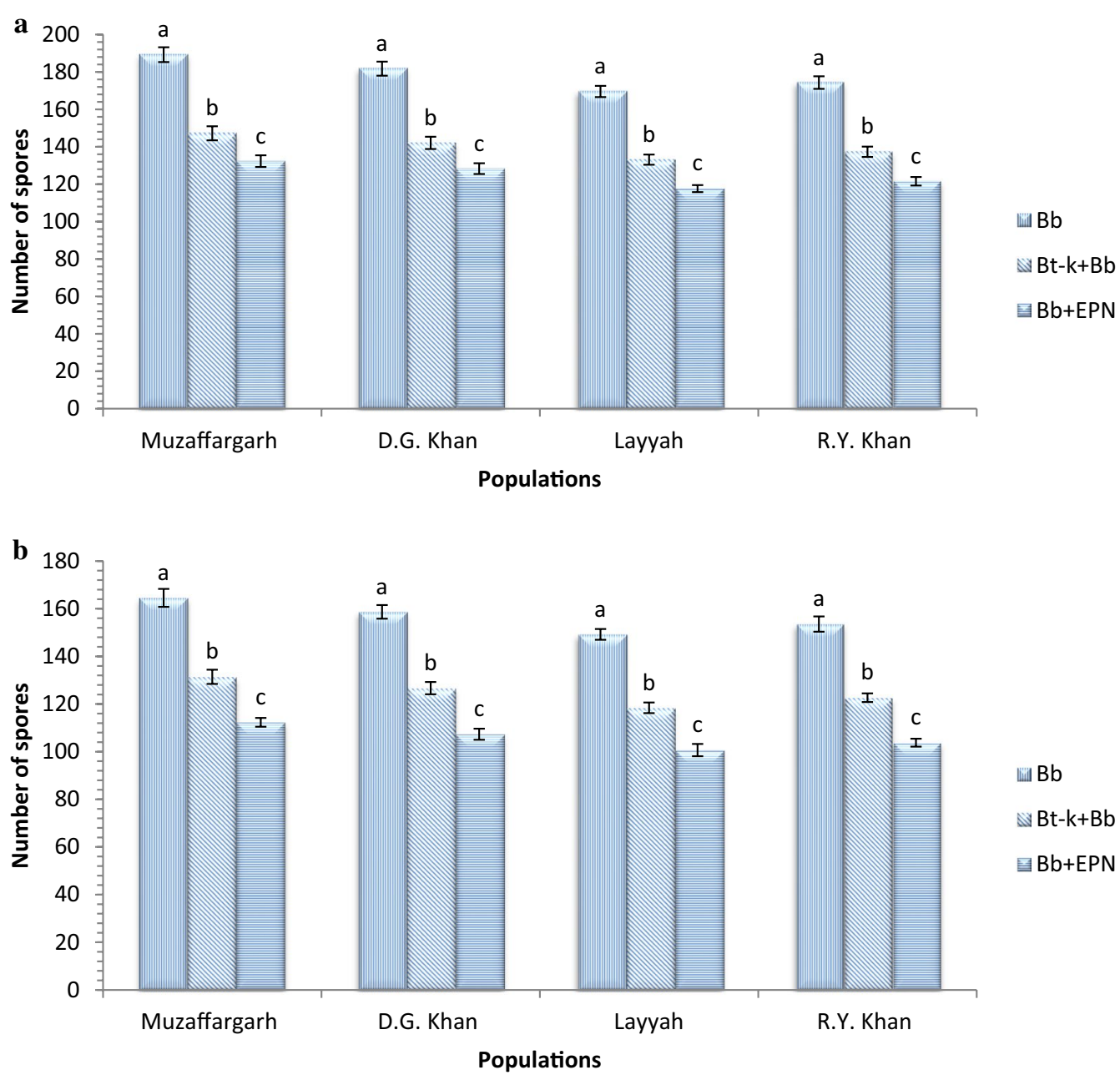

Fig. 2 a Sporulation (conidia ml $\left.{ }^{-1}\right)$ in Rhynchophorus ferrugineus larvae treated with $B t-k\left(70 \mathrm{~g} \mathrm{~g} \mathrm{~g}^{-1}\right)$, Beauveria bassiana $\left(1 \times 10^{7} \mathrm{conidia} \mathrm{ml}^{-1}\right)$ and Heterorhabditis bacteriophora (300 $\mathrm{lJs} \mathrm{ml}{ }^{-1}$ ) applied alone or in combination. Treatments followed by the same letter within each treatment are not significantly different; HSD test $P \leq 0.05$ (Bt-k: Bacillus thuringiensis var. kurstaki, Bb: Beauveria bassiana, EPN: Heterorhabditis bacteriophora). b Sporulation (conidia ml-1) in Rhynchophorus ferrugineus adults treated with Bt-k $\left(70 \mathrm{\mu g} \mathrm{g}^{-1}\right)$, Beauveria bassiana $\left(1 \times 10^{7} \mathrm{conidia} \mathrm{ml}^{-1}\right)$ and Heterorhabditis bacteriophora $\left(300 \mathrm{IJ} \mathrm{ml}^{-1}\right)$ applied alone or in combination. Treatments followed by the same letter within each treatment are not significantly different; HSD test $P \leq 0.05$ (Bt-k: Bacillus thuringiensis var. kurstaki, Bb: Beauveria bassiana, EPN: Heterorhabditis bacteriophora)

was applied alone against laboratory population (Fig. 2a, b); however, low rate of sporulation was observed in the treatments where $H$. bacteriophora and B. bassiana were applied in combined manners. Similar pattern in mycosis and sporulation was observed in other RPW populations.

\section{Insects affected by EPN and their production}

Significant difference in infection rate by nematodes was observed for larvae (D.G. Khan: $F_{2},{ }_{26}=17.19, P<0.01$; Layyah: $F_{2}$, ${ }_{26}=29.9, P<0.01$; Muzaffargarh: $F_{2}$, ${ }_{26}=11.2$, $P<0.01$; R.Y. Khan: $\left.F_{2},{ }_{26}=15.0, P<0.01\right)$ and adults (D.G. Khan: $F_{2},{ }_{26}=7.98, P<0.01$; Layyah: $F_{2},{ }_{26}=10.6$, $P<0.01$; Muzaffargarh: $F_{2}, 26=9.29, P<0.01$; R.Y. Khan: $\left.F_{2},{ }_{26}=8.27, P<0.01\right)$. Maximum lethality in affected individuals was 92.40 and $81.29 \%$ in larvae and adults, respectively (Fig. 3a, b). Likewise, significant difference was recorded in nematode production both for larvae (D.G. Khan: $F_{2},{ }_{26}=34.0, P<0.01$; Layyah: $F_{2},{ }_{26}=85.1$, $P<0.01$; Muzaffargarh: $F_{2},{ }_{26}=31.0, P<0.01$; R.Y. Khan: $F_{2},{ }_{26}=62.4, P<0.01$ ) and adults (D.G. Khan: $F_{2},{ }_{26}=25.4$, $P<0.01$; Layyah: $F_{2},{ }_{26}=46.8, P<0.01$; Muzaffargarh: $F_{2}$, ${ }_{26}=17.5, P<0.01$; R.Y. Khan: $\left.F_{2},{ }_{26}=53.3, P<0.01\right)$. Maximum number of nematode productions, on white trap in larvae (178 IJs ml ${ }^{-1}$ ) and adults (153 IJs ml ${ }^{-1}$ ) (total volume $10 \mathrm{ml}$ ), was observed in treatments where $\mathrm{H}$. bacteriophora was applied alone against larvae and adults in the laboratory population (Fig. 4a, b). However, low infection rate and nematode's production were recorded 

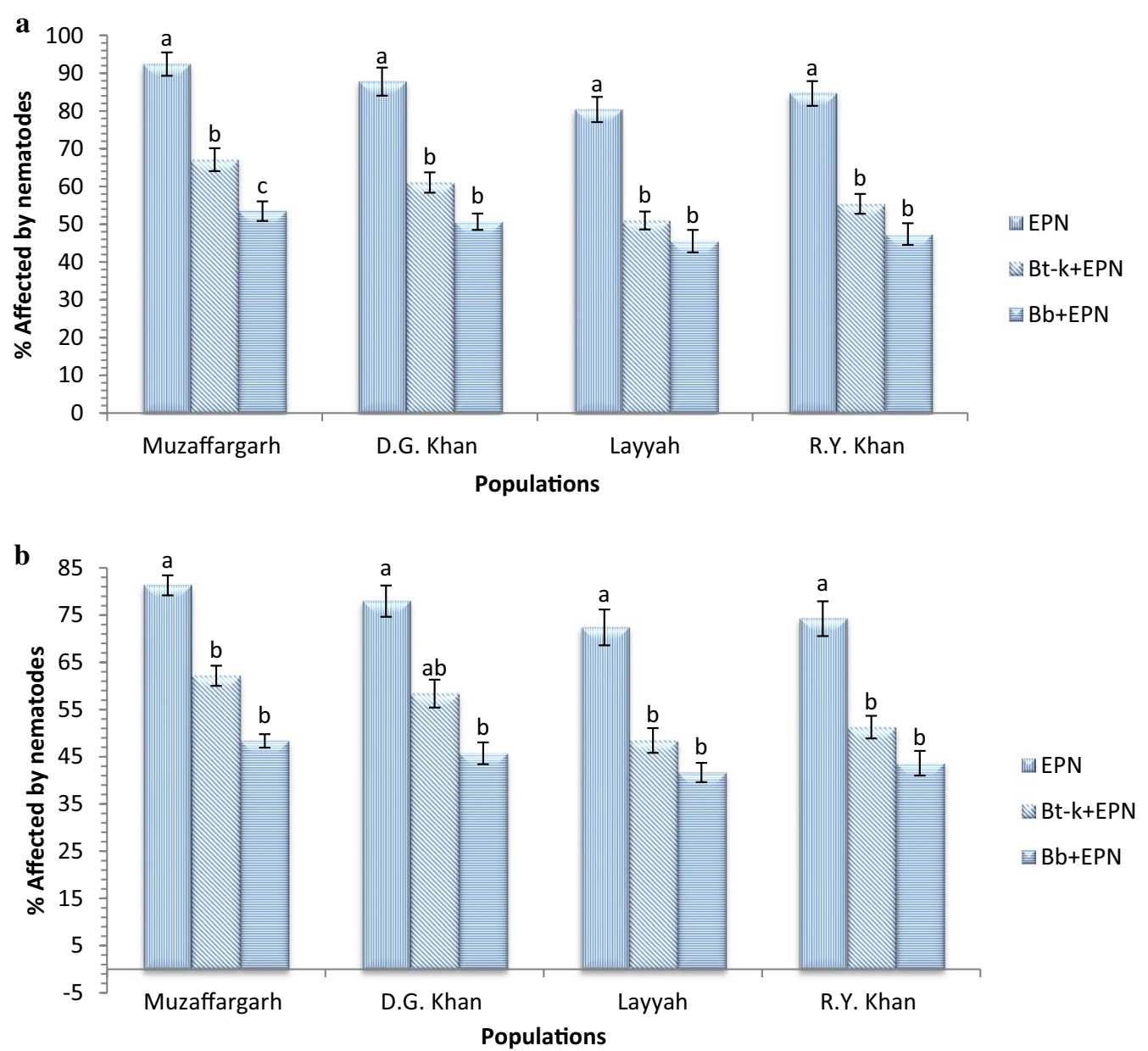

Fig. 3 a Rhynchophorus ferrugineus larvae affected by Heterorhabditis bacteriophora treated with Bt- $k\left(70 \mu \mathrm{g} \mathrm{g}^{-1}\right)$, Beauveria bassiana $\left(1 \times 10^{7}\right.$ conidia $\left.\mathrm{ml}^{-1}\right)$ and Heterorhabditis bacteriophora $\left(300 \mathrm{IJ} \mathrm{ml}^{-1}\right)$ applied alone or in combination. Treatments followed by the same letter within each treatment are not significantly different; HSD test $P \leq 0.05$ (Bt-k: Bacillus thuringiensis var. kurstaki, Bb: Beauveria bassiana, EPN: Heterorhabditis bacteriophora). b Rhynchophorus ferrugineus adults affected by Heterorhabditis bacteriophora treated with Bt-k $\left(70 \mu \mathrm{g} \mathrm{g}{ }^{-1}\right)$, Beauveria bassiana $\left(1 \times 10^{7}\right.$ conidia $\left.\mathrm{ml}^{-1}\right)$ and Heterorhabditis bacteriophora $\left(300 \mathrm{lJs} \mathrm{ml}^{-1}\right)$ applied alone or in combination. Treatments followed by the same letter within each treatment are not significantly different; HSD test $P \leq 0.05$ (Bt-k: Bacillus thuringiensis var. kurstaki, Bb: Beauveria bassiana, EPN: Heterorhabditis bacteriophora)

in the treatments where $H$. bacteriophora and B. bassiana were integrated. Similar trend was recorded for the other RPW populations.

\section{Discussion}

Based on the results of the present study, the integrated use of entomopathogens is effective, but the outcomes were highly influenced by the combination of agents (Bt$k$ plus B. bassiana, Bt-k plus H. bacteriophora or B. bassiana plus $H$. bacteriophora), host stage and the exposure interval. The integration of entomopathogenic nematodes + fungi and bacteria is entirely new approach to control RPW larvae and adults as the pathogens exhibited virulence against both developmental stages of RPW.
However, when combined either agent, the pathogenicity was enhanced, except larvae at last count. Numerous studies have documented sole and integrated applications of entomopathogens against number of insect pests (Usman et al. 2020). The entomopathogens, that curtail RPW infestations, are more effective in managing weevil population than chemical insecticides and fumigants (ElSufty et al. 2011).

In this study, the combined treatments of B. bassi$a n a+B t-k$ exhibited enhanced larval and adult mortality than their individual applications. Integrated application of $B$. bassiana $+B$. thuringiensis acted synergistically and weakened the insect immune response system which allows entomopathogens to inflict high mortality (Wakil 

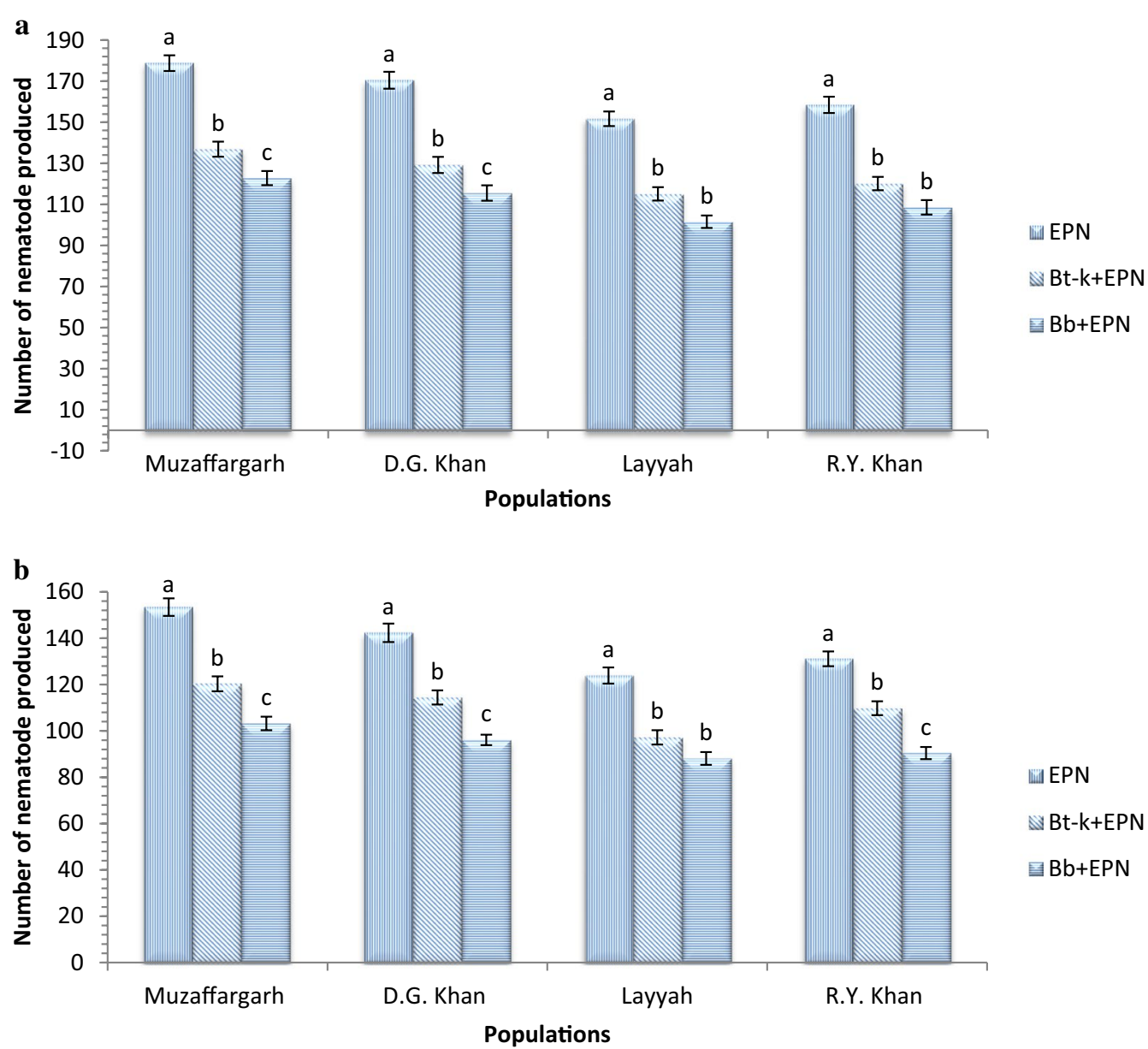

Fig. 4 a Nematode production (IJs ml $\left.{ }^{-1}\right)$ in larvae of Rhynchophorus ferrugineus treated with Bt-k $\left(70 \mu \mathrm{g} \mathrm{g}^{-1}\right)$, Beauveria bassiana $\left(1 \times 10^{7}\right.$ conidia $\mathrm{ml}^{-1}$ ) and Heterorhabditis bacteriophora $\left(300 \mathrm{IJs} \mathrm{ml}{ }^{-1}\right.$ ) applied alone or in combination. Treatments followed by the same letter within each treatment are not significantly different; HSD test $P \leq 0.05$ (Bt-k: Bacillus thuringiensis var. kurstaki, Bb: Beauveria bassiana, EPN: Heterorhabditis bacteriophora). $\mathbf{b}$ Nematode production (IJs ml $\left.{ }^{-1}\right)$ in adults of Rhynchophorus ferrugineus treated with Bt-k $\left(70 \mu \mathrm{g} \mathrm{g}^{-1}\right)$, Beauveria bassiana $\left(1 \times 10^{7}\right.$ conidia $\mathrm{ml}^{-1}$ ) and Heterorhabditis bacteriophora $\left(300 \mathrm{IJ} \mathrm{ml}^{-1}\right.$ ) applied alone or in combination. Treatments followed by the same letter within each treatment are not significantly different; HSD test $P \leq 0.05$ (Bt-k: Bacillus thuringiensis var. kurstaki, Bb: Beauveria bassiana, EPN: Heterorhabditis bacteriophora)

et al. 2020). When fungal spores gain access to the insect gut, it boosts the infection of $B t$ spores, consequently help each other in retardation of normal physiological functions of an insect host. Inversely, the $B t$ treatments lead the gut to septicemia causing the insect to stop feeding, and weakening the host immune system. This will favor the B. bassiana to work efficiently with very low resistant of the host immune system thereby increasing mortality. These findings are in line with Allee et al. (1990) who reported the synergistic interaction of $B$. bassiana and $B t$ against grubs of Colorado potato beetle.

We have observed the highest mortality by EPNs in combined treatments with Bt-k and B. bassiana of both larvae and adults. While, in experiment conducted by
Koppenhöfer and Kaya (1997), the results did not indicate a potential synergism between $B t$ var. kurstaki and $H$. bacteriophora. This might be attributed to the inadequate weather conditions in the days after nematode application.

Obtained results are also in accordance with the findings of many researchers who reported additive or synergistic interactions among nematodes and fungi (Manzoor et al. 2020). Contrarily, Shapiro-Ilan et al. (2004) found antagonism between EPNs and $P$. fumosoroseus. Such antagonism may be due to pathogen interactions prior to or during infection. The findings also suggested that percent mycosis and sporulation were high in treatment where $B$. bassiana was 
applied alone. Similar results were reported by Tefera and Pringle (2003) who determined a high mycosis and sporulation on larvae of Chilo partellus (F.) (Pyralidae: Lepidoptera). In case of combined applications, all insects died quickly and fungus sporulated in a small number of cadavers and created few conidia. Similar results were also reported by Malik et al. (2016) who reported high mycosis and sporulation against RPW larvae. Similar phenomenon could be attributing the higher IJs production in sole treatment of nematodes.

A good knowledge of biological parameters of RPW and, most importantly, the interaction among entomopathogens could play a key role to expand RPW-IPM programs. This calls for the isolation and identification of more virulent strains of entomopathogens. Moreover, the field evaluation of these substances in combined manners can provide substantial information and help in developing new strategies for IPM based crop production systems (Manachini et al. 2011).

\section{Conclusions}

The present study revealed that B. bassiana, Bt-k and $H$. bacteriophora can effectively kill the RPW larvae and adults. They also exert the detrimental effect on their growth and development which can be used effectively against this pest. Moreover, mycosis and nematode production is the peculiar characters of EPFs and EPNs that can cause secondary infection and novel mode of actions of these pathogenic agents can become a useful component in an IPM program against RPW.

\section{Abbreviations}

Bt-k: Bacillus thuringiensis Var. kurstaki; D: Day; D.G. Khan: Dera Ghazi Khan; EPF: Entomopathogenic fungi; EPN: Entomopathogenic nematodes; IJs: Infective juveniles; IPM: Integrated pest management; L: Light; MI: Milliliter; RPW: Red palm weevil; R.Y. Khan: Rahim Yar Khan.

\section{Acknowledgements}

We are highly obliged to HEC for providing funds for research and their unwavering support throughout study.

\section{Authors' contributions}

All authors equally participated in this study. WW conceived and designed the study. MAQ and MY conducted the research and prepared first draft. SA performed statistical analysis and prepared graphs. AS, MAA and MS supervised, reviewed and edited MS for final submission. All authors read and approved the final manuscript.

\section{Funding}

This research work was supported by the Higher Education Commission (HEC), Islamabad, Pakistan under 5000 Indigenous Scholarships Scheme to the research scholars bearing award number (112-30536-2AV1-263).

\section{Availability of data and materials}

The datasets used and/or analyzed during the current study are available from the corresponding author on reasonable request.

\section{Declarations}

Ethics approval

Not applicable.

Consent of publication

Not applicable.

\section{Competing interests}

The authors declare that they have no competing interests.

\section{Author details}

${ }^{1}$ Department of Entomology, The Islamia University of Bahawalpur, Bahawalpur 63100, Pakistan. ${ }^{2}$ Department of Continuing Education, University of Agriculture, Faisalabad 38000, Pakistan. ${ }^{3}$ Department of Entomology, University of Agriculture, Faisalabad 38000, Pakistan. ${ }^{4}$ Department of Entomology, MNS University of Agriculture, Multan 60000, Pakistan. ${ }^{5}$ Key Laboratory of Bio-Pesticide Innovation and Application of Guangdong Province, College of Agriculture, South China Agricultural University, Guangzhou 510000, China.

Received: 19 July 2021 Accepted: 14 October 2021

Published online: 28 October 2021

\section{References}

Abbott WS (1925) A method of computing the effectiveness of an insecticide. J Econ Entomol 18:265-267

Abdel-Raheem M, Alghamdi HA, Reyad NF (2020) Nano essential oils against the red palm weevil, Rhynchophorus ferrugineus Olivier (Coleoptera: Curculionidae). Entomol Res 50:215-220

Allee LL, Goettel MS, Golberg A, Whitney HS, Roberts DW (1990) Infection by Beauveria bassiana of Leptinotarsa decemlineata larvae as a consequence of fecal contamination of the integument following per os inoculation. Mycopathologia 111:17-24

Ashry I, Mao Y, Al-Fehaid Y, Al-Shawaf A, Al-Bagshi M, Al-Brahim S, Ng TK, Ooi BS (2020) Early detection of red palm weevil using distributed optical sensor. Sci Rep 10:3155

Atwa AA, Hegazi EM (2014) Comparative susceptibilities of different life stages of the red palm weevil (Coleoptera: Curculionidae) treated by entomopathogenic nematodes. J Econ Entomol 107(4):1339-1347

El-Sufty R, Al-Bgham S, Al-Awash S, Shahdad A, Al-Bathra A (2011) A trap for auto dissemination of the entomopathogenic fungus Beauveria bassiana by red palm weevil adults in date palm plantations. Egypt J Biol Pest Control 21:271-276

Faleiro JR (2006) A review of the issues and management of the red palm weevil Rhynchophorus ferrugineus (Coleoptera: Rhynchophoridae) in coconut and date palm during the last one hundred years. Int J Trop Insect Sci 26:135-154

Hernández CS, Andrew R, Bel Y, Ferre J (2005) Isolation and toxicity of Bacillus thuringiensis from potato-growing areas in Bolivia. J Inver Pathol 88:8-16

Kaya HK, Stock SP (1997) Techniques in insect nematology. In: Lacey LA (ed) Manual of techniques in insect pathology. Academic Press, London, pp 281-324

Koppenhöfer AM, Kaya HK (1997) Additive and synergistic interaction between entomopathogenic nematodes and Bacillus thuringiensis for scarab grub control. Biol Control 8:131-137

Malik MA, Manzoor M, Ali H, Muhammad A, Islam S, Qasim M, Ahmad N, Idrees A, Muhammad A, Saqib HSA (2016) Evaluation of imidacloprid and entomopathogenic fungi, Beauveria bassiana against the red palm weevil Rhynchophorus ferrugineus (Coleoptera: Curculionidae). J Ent Zool Stud 4(1):262-268

Manachini B, Lo Bue P, Peri E, Colazza S (2009) Potential effects of Bacillus thuringiensis against adults and older larvae of Rhynchophorus ferrugineus. IOBC/WPRS Bull 45:239-242

Manachini B, Arizza V, Parrinello D, Parrinello N (2011) Hemocytes of Rhynchophorus ferrugineus (Olivier) (Coleoptera: Curculionidae) and their response to Saccharomyces cerevisiae and Bacillus thuringiensis. J Inver Pathol 106:360-365 
Manzoor M, Ahmad JN, Giblin-Davis RM, Javed N, Haider MS (2020) Effects of entomopathogenic nematodes and/or fungus on the red palm weevil, Rhynchophorus ferrugineus (Curculionidae: Coleoptera). Nematology 22(10):1193-1207

Martín MM, Cabello T (2006) Manejo de la cría del picudo rojo de la palmera, Rhynchophorus ferrugineus (Olivier, 1790) (Coleoptera, Dryophthoridae), en dieta artificial y efectos en su biometría y biología. Boletín De Sanidad Vegetal De Plagas 32:631-641

Mendesil E, Shumeta Z, Anderson P, Rämert B (2016) Smallholder farmers' knowledge, perceptions and management of pea weevil in north and North-Western Ethiopia. Crop Prot 81:30-37

Minitab (2003) MINITAB release 14 for windows. Minitab Inc., State College Poinar GO Jr (1990) Taxonomy and biology of Steinernematidae and Heterorhabditidae. In: Gaugler R, Kaya HK (eds) Entomopathogenic nematodes in biological control. CRC Press, Boca Raton, pp 23-61

Shapiro-llan DI, Jackson M, Reilly CC, Hotchkiss MW (2004) Effects of combining an entomopathogenic fungi or bacterium with entomopathogenic nematodes on mortality of Curculio caryae (Coleoptera: Curculionidae). Biol Control 30:119-126

Sokal RR, Rohlf FJ (1995) Biometry, 3rd edn. Freedman and Company, New York

Tefera T, Pringle KL (2003) Effect of exposure method to Beauveria bassiana and conidia concentration on mortality, mycosis, and sporulation in cadavers of Chilo partellus (Lepidoptera: Pyralidae). J Invertebr Pathol 80:90-95

Usman M, Gulzar S, Wakil W, Wu W, Piñero JC, Leskey TC, Nixon LJ, Oliveira-Hofman C, Toews MD, Shapiro-Ilan D (2020) Virulence of entomopathogenic fungi to Rhagoletis pomonella (Diptera: Tephritidae) and interactions with entomopathogenic nematodes. J Eco Entomol 113(6):2627-2633

Wakil W, Yasin M, Shapiro-Ilan D (2017) Effects of single and combined applications of entomopathogenic fungi and nematodes against Rhynchophorus ferrugineus (Olivier). Sci Rep 7:5971

Wakil W, Tahir M, Al-Sadi AM, Shapiro-Ilan D (2020) Interactions between two invertebrate pathogens: an endophytic fungus and an externally applied bacterium. Front Microbiol 11:522368

White GF (1927) A method for obtaining infective nematode larvae from cultures. Science 66:302-303

Woodring L, Kaya HK (1988) Steinernematid and heterorhabditid nematodes: a handbook of techniques. Series Bull, vol 331. Arkansas Agricultural Experiment Station, Fayetteville

Wraight SP, Ramos ME (2005) Synergistic interaction between Beauveria bassiana and Bacillus thuringiensis tenebrionis based biopesticides applied against field populations of Colorado potato beetle larvae. J Invertebr Pathol 90:139-150

\section{Publisher's Note}

Springer Nature remains neutral with regard to jurisdictional claims in published maps and institutional affiliations.

\section{Submit your manuscript to a SpringerOpen ${ }^{\circ}$ journal and benefit from:}

- Convenient online submission

- Rigorous peer review

- Open access: articles freely available online

- High visibility within the field

- Retaining the copyright to your article

Submit your next manuscript at $\boldsymbol{\nabla}$ springeropen.com 